\title{
The conservation of bees: a global perspective*
}

\author{
Mark J.F. BROWN ${ }^{1}$, Robert J. PAXTON ${ }^{2}$ \\ ${ }^{1}$ School of Biological Sciences, Royal Holloway, University of London, Egham, Surrey, TW20 0EX, UK \\ ${ }^{2}$ School of Biological Sciences, Queen's University Belfast, 97 Lisburn Road, Belfast BT9 7BL, UK
}

Received 4 March 2009 - Accepted 5 March 2009

\begin{abstract}
Bees are major pollinators of Angiosperms and therefore their apparent decline is of importance for humans and biodiversity. We synthesise results of 12 recent reviews to provide a global picture of the threats they face. Habitat loss is the major threat to bee diversity, whilst invasive species, emerging diseases, pesticide use, and climate change also have the potential to impact bee populations. We suggest that future conservation strategies need to prioritise (i) minimising habitat loss, (ii) making agricultural habitats bee-friendly, (iii) training scientists and the public in bee taxonomy and identification, (iv) basic autecological and population genetic studies to underpin conservation strategies, (v) assessing the value of DNA barcoding for bee conservation, (vi) determining the impact of invasive plants, animals, parasites and pathogens, and (vii) integrating this information to understand the potential impact of climate change on current bee diversity.
\end{abstract}

Apoidea / biodiversity / pollination / conservation / ecosystem service

\section{INTRODUCTION}

Bees are the major pollinators of wild plants and crops in terrestrial ecosystems (Buchmann and Nabhan, 1996; Klein et al., 2007). As such, they are essential providers of the ecosystem service of pollination (Costanza et al., 1997). Numerous studies have demonstrated their economic value to the agricultural industry (e.g., Klein et al., 2007). However, their value to natural ecosystems is harder to quantify (Costanza et al., 1997). Given the projections for human population growth to $\sim 9$ billion by 2050 (United Nations, 2004) and the corresponding increasing conversion of landscapes to agricultural use (Tilman et al., 2001), the importance of bees to human survival and the maintenance of much of terrestrial biodiversity can only increase over the coming years.

Corresponding author: M.J.F. Brown, mark.brown@rhul.ac.uk

* Manuscript editor: Tomas Murray
Hand-in-hand with our need for bees comes increasingly strong evidence that they are in decline (Williams P.H., 1982; Biesmeijer et al., 2006; Fitzpatrick et al., 2007). This decline appears to be mainly anthropogenically driven, with a number of factors playing major causal roles. Habitat loss (habitat degradation and outright destruction) appears to be the major causal factor in the decline of bees, as it is for the decline of biodiversity in general (Foley et al., 2005). Habitat fragmentation, a direct result of habitat loss, will impact on surviving populations, either through genetic isolation and subsequent inbreeding (Zayed, 2009) or simply the inability of small habitat islands to support viable bee populations (e.g., Ellis et al., 2006). Invasive and emergent species, be they plants, other free-living animals or parasites and pathogens, can significantly impact on bee populations in surviving habitats (Stout and Morales, 2009). Climate change is likely to have a huge impact on remaining bee biodiversity in the future, as it has on other insects already (Parmesan et al., 1999), although 
as yet no studies have demonstrated a clear causal effect on bee population persistence. Of course, habitat loss, fragmentation, invasive species and climate change are not independent factors (Brook et al., 2008); they interact with each other and thus their impact on bee populations is unlikely to be simple to predict.

This issue of Apidologie contains reviews of many of these factors, across different taxonomic groups of bees, and across different geographical realms. Our aim in this paper is to synthesise these reviews to draw out what is known about bee decline at a global scale, what remains unknown, and how we might go forward to a world where bee diversity is managed and conserved sustainably for future generations.

\section{SYNTHESIS OF FACTORS IMPACTING BEES}

Reviews on solitary bees in Australia (Batley and Hogendoorn, 2009), Central and South America (Freitas et al., 2009), the Palaearctic (Patiny et al., 2009), and subSaharan Africa and Madagascar (Eardley et al., 2009), on bumble bees worldwide (Williams P.H. and Osborne, 2009); and on honey bees in Asia (Oldroyd and Nanork, 2009), Africa (Dietemann et al., 2009) and Europe (De La Rúa et al., 2009) enable us to assess the taxonomic and geographic extent of the causal factors that have been implicated in bee decline. We would note, however, that we still remain largely ignorant of the situation of solitary bees in Asia and North America, and that these reviews also indicate large knowledge gaps for these taxa in these geographic realms.

Table I lists five factors: (i) habitat loss, fragmentation and degradation, (ii) invasive species, (iii) parasites and disease, (iv) exploitation, (v) extinction cascades, and (vi) climate change; and the major taxa and realms covered by the reviews listed above. As we have already stated, these factors do not act independently and therefore it is often difficult to disentangle their impacts to determine the cause behind a given decline (Williams P.H. and Osborne, 2009). Nevertheless, it is clear that habitat loss is the most universal and high impact factor driving bee declines (mentioned in 11 review articles of this issue). This is not surprising. Approximately 38\% of the earth's surface is used for agricultural purposes, much of it for intensive farming, and grasslands and tropical forests are a fraction of their past extent (Foley et al., 2005). After habitat loss, invasive species and parasites and disease appear to be the most widespread and documented threats to bee populations (mentioned in 10 review articles of this issue; and see Stout and Morales, 2009). Nevertheless, climate change could be the major future threat. Conservation is mostly predicated on spatially-constrained reserves, or agri-environment schemes. The impact of climate change will be to shift species ranges (e.g., Parmesan et al., 1999) and to render current agricultural practices regionally unviable.

\section{GAPS IN OUR KNOWLEDGE}

If nothing else, the reviews in this issue highlight how much remains to be learned about bees and the threats that they face. The biggest problem is the lack of good data on bee species distributions and abundance. This is true not only in areas with few local experts and little history of Western-style natural science (Eardley et al., 2009) but also in Europe, where we have arguably the broadest and deepest knowledge of the bee fauna (De La Rúa et al., 2009; Patiny et al., 2009; Williams P.H. and Osborne, 2009). Furthermore, much of the bee fauna undoubtedly remains undescribed (e.g., Eardley et al., 2009). If we do not know where bee species live, and how abundant they are, it is almost impossible to measure decline and generate prioritised and meaningful conservation strategies.

The recent upsurge in bee conservation studies has been driven by the rallying call of pollination decline. Nevertheless, it remains true that, apart from a small number of ecosystems (e.g., Memmot et al., 2004) and taxa, we know almost nothing about the pollination biology of many agricultural crops and flowering plants (Klein et al., 2007). If policy requires a focus on the economically important ecosystem service of pollination, basic pollination 


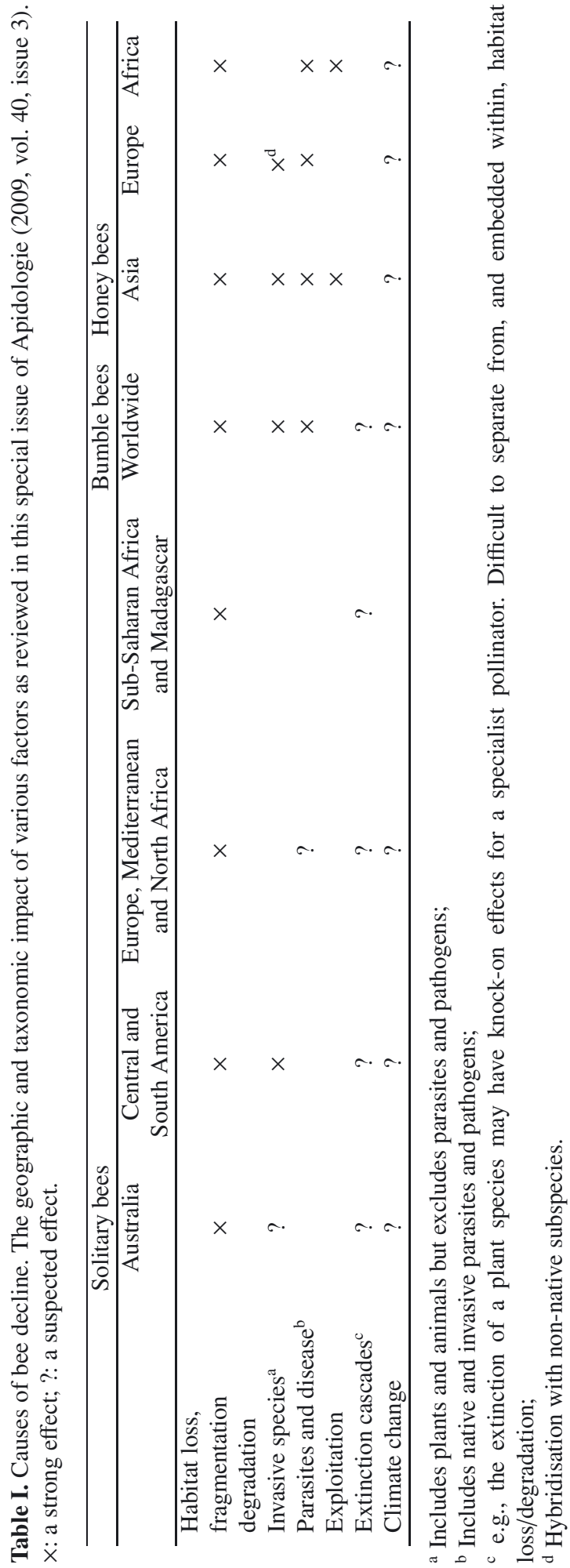


studies are required to determine which pollinators should be prioritised for conservation. This is especially true given that recent network analyses have demonstrated that plantpollinator interactions are driven by a few, generalist pollinator species (Memmot et al., 2004), and that world yields of pollinationdependent crops have not declined in recent years (Aizen et al., 2008).

While it is widely recognised that insect populations in general fluctuate widely from year to year (Andrewartha and Birch, 1954), such fluctuations have rarely been measured in bee populations (Roubik, 2001; Williams N.M. et al., 2001) and their implications for assessing bee population declines have scarcely been addressed (Patiny et al., 2009; Murray et al., 2009). Similarly, whilst a few studies have examined connectivity, isolation and gene flow in wild bee populations (reviewed in Zayed, 2009), outside of the genera Apis and Bombus we know little about the population and conservation genetics of bees. The potential impact of introgression from introduced bee species is also poorly, if at all understood (see Stout and Morales, 2009).

Invasive species are going to be an increasing challenge in the future, but as Stout and Morales (2009) point out, our knowledge of the impacts of invasive species is fragmentary at best, even with respect to the relatively wellstudied honey bee in Europe. Though a population genetic signature of non-native subspecies of Apis mellifera can be detected in indigenous European subspecies, the effects of such intraspecific hybridisation on colony health and population persistence have been harder to discern (De La Rúa et al., 2009). Alas bee scientists are only too aware of the negative impacts of exotic pests and pathogens on honey bees; European A. mellifera across most of the world are nowadays plagued by the exotic parasitic mite, Varroa destructor, that transmits a range of emergent viral pathogens, usually leading to colony demise (Cox-Foster et al., 2007). Yet only recently has pathogen spill-over, the transfer of emergent and exotic pathogens from managed honey bees and bumble bees to other 'wild bees', been appreciated as a potential major causal factor in bee declines (Williams P.H. and Osborne, 2009).
As we noted above, climate change is likely to have a significant impact on bee populations worldwide, due to both changes in temperature and general meteorological conditions, and in the loss of coastal areas through sea-level rises. Currently, we are aware of only one study that looks at the interaction between species range changes and climate (Williams P.H. et al., 2007). We are clearly lacking data on both (i) the climate envelopes for the vast majority of bee species, and (ii) how climate change will impact on all aspects of the bee life-cycle, from winter hibernation through foraging to reproduction.

Eight of the 12 review articles in this issue have identified pesticides as a potential or realised cause of bee decline. Recent (spring 2008) honey bee losses in SW Germany due to neonicotinoid poisoning led the German federal government to ban temporarily such insecticides as seed dressings to prevent further bee losses (reviewed in De La Rúa et al., 2009), a position that other EU countries and environmentally aware farmers (e.g. Co-op, 2009) are also following. Bee-keepers act as ready surveillance monitors for acute pesticide poisoning of honey bees. Yet the impacts of the neonicotinoid mis-use incident in SW Germany on other bee species and invertebrate biodiversity at large are unknown but undoubtedly profound, as are the sublethal effects of pesticides on all bee species. The impact of genetically modified organisms (GMOs) is more contentious. There is no clear evidence of a negative impact of GMO plants that constitutively express insecticides on bees (O'Callaghan et al., 2005; Malone et al., 2005) and some are widely marketed (though some EU countries still forbid their cultivation; see Abbott, 2009).

\section{MANIFESTO: A FRAMEWORK FOR FUTURE BEE CONSERVATION}

Action is clearly needed if we are to arrest and reverse current declines in bee populations, and thus safeguard their future biodiversity. Given that the obvious first step to halt land-use change - is economically and 
politically unlikely to occur, what can be done to minimise the biggest threat to bee biodiversity? Clearly, one approach is to embed biodiversity maintenance within agricultural development. This is currently being undertaken in Europe through agri-environment schemes (Byrne and Fitzpatrick, 2009). While much research remains to be done to assess the effectiveness of such schemes, minimising intensive agricultural development and maintaining natural habitats within the agricultural mosaic should go some way to supporting bee diversity.

A second important action is to prioritise the training and support of scientists in bee alpha taxonomy. That the number of taxonomists in general is declining is well known, and several articles in this issue (Batley and Hogendoorn, 2009; Eardley et al., 2009; Patiny et al., 2009) make this point specifically for bee taxonomists, whilst another three reviews mention the 'taxonomic imperative', the lack of taxonomic expertise and resources. While DNA barcoding may go some way towards helping us measure and understand bee species richness (Zayed, 2009), it is not a general panacea or a replacement for traditional taxonomy (e.g., Elias et al., 2007).

Thirdly, we are in dire need of basic autecological (Murray et al., 2009) and pollination studies outside of well-known or model crops, flowering plant species and bee taxa. Such studies will be central to prioritising conservation based on ecosystem service provision. They will also provide the data necessary to combine with climate change models to determine how this inevitable change to our planet's systems will impact on pollinator distribution and abundance.

Fourthly, and illustrated by recent dramatic declines in American honey bee populations (Cox-Foster et al., 2007), we need to understand how both native and invasive parasites and pathogens impact individual bees, and how this impact ramifies into population-level effects.

In addition to the need for basic science, policy (Byrne and Fitzpatrick, 2009) and research (Murray et al., 2009) for bee conservation should be integrated horizontally across countries and regions, and vertically from international to local scales. Current interest and efforts need to be maximised, and must not be allowed to peter out.

In conclusion, we have a good idea of the general factors promoting the decline of bees. We know what we need to do, and we know what we need to find out. While numerous studies are currently being conducted, it is up to the bee research community to make the argument to governments and other funders of research and conservation that bees are essential for a healthy planet and a healthy human population. If we fail to make this argument soon and convincingly, we will only have ourselves to blame.

\section{ACKNOWLEDGEMENTS}

Our thanks go to all the authors of reviews in this special issue of Apidologie and to the reviewers of the manuscripts, who have not only provided the material for this synthesis but more importantly who have contributed intellectually to an issue of the journal whose success will hopefully be measured in a turn around in the alarming decline of bees worldwide. We are also indebted to Tomás Murray for efficient handling of this paper.

MJFB was funded by Science Foundation Ireland grant EEE0BF131.

La conservation des abeilles : perspective globale.

Apoidea / biodiversité / pollinisation / protection / service aux écosystèmes

Zusammenfassung - Die Erhaltung der Bienen: Eine globale. Bienen sind die wichtigsten Bestäuber von wildblühenden und landwirtschaftlichen Nutzpflanzen. Das hat zur Konsequenz, dass ihre offensichtliche Abnahme eine bedeutende Sorge um die Ernährung der Menschen und die Erhaltung der Biodiversität im großen Maßstab darstellen sollte. Hier stellen wir die Ergebnisse von 12 neuesten Übersichtsartikeln zusammen, um ein globales Bild der Abnahme der Bienen und von den Bedrohungen, denen die Bienen ausgesetzt sind $\mathrm{zu}$ erhalten (Tab. I). Ganz offensichtlich stellt der Verlust an Lebensräumen die hauptsächliche Bedrohung der Vielfalt der Bienen wie der Biodiversität im Allgemeinen dar. Es können aber auch andere Faktoren wie invasive Arten, das Auftauchen 
neuer Krankheiten, die Verwendung von Pestiziden und der Klimawandel zu bedeutenden Belastungen für die Bienenpopulationen werden. Obwohl es sehr schwierig ist, den Beitrag aller dieser Faktoren zu trennen, ist dies aber eine unabdingbare Aufgabe wenn wir die Bienendiversität erhalten, unterstützen oder wiederherstellen wollen. Es ist offensichtlich, dass die derzeitigen Erhaltungsanstrengungen durch den Mangel an grundlegenden Daten zur Verteilung, Häufigkeit, Ökologie und Populationsgenetik behindert werden. Wir schlagen vor, dass zukünftige Erhaltungsstrategien hauptsächlich auf folgende Punkte ausgerichtet werden sollten: (i) die Minimierung des Verlustes an Lebensraum, (ii) die bienenfreundliche Gestaltung landwirtschaftlicher Habitate, (iii) die Unterweisung von Wissenschaftlern und der Öffentlichkeit in Bienentaxonomie und der Bestimmung der Arten, (iv) der Erstellung von grundlegenden autökologische und populationsgenetische Studien zur Untermauerung der Erhaltungsmassnahmen, (v) der Ermittlung der Nutzbarkeit von DNA Barcoding für die Bienenerhaltung, (vi) der Bestimmung der Auswirkungen invasiver Pflanzen, Tieren, Parasiten und Pathogenen, und (vii) der Zusammenführung dieser Information, um die möglichen Auswirkungen des Klimawechsels auf die verbleibende Bienendiversität verstehen zu können. Zusätzlich zu diesen Prioritäten sollte das vielfältige Angebot an internationalen, nationalen und regionalen Ansätzen und politischen Maßnahmen für die Bienenerhaltung zusammengeführt werden, um Überschneidungen aufzulösen und ein zusammenhängendes Rahmenwerk für die Erhaltungs- und Wiederherstellungsaktivitäten zu schaffen. Während Bienen aller Art über den ganzen Globus hinweg Bedrohungen gegenüberstehen, glauben wir, dass es uns mit abgestimmtem und wissenschaftlich fundiertem Handeln möglich ist die Diversität der Bienen für die zukünftigen Generationen zu erhalten oder wiederherzustellen.

\section{Apoidea / Biodiversität / Bestäubung / Erhal- tung / Ökosystemdienstleistung}

\section{REFERENCES}

Abbott A. (2009) European disarray on transgenic crops, Nature 457, 946-947.

Aizen M.A., Garibaldi L.A., Cunningham S.A., Klein A.M. (2008) Long-term global trends in crop yield and production reveal no current pollination shortage but increased pollinator dependency, Curr. Biol. 18, 1572-1575.

Andrewartha H.G., Birch L.C. (1954) The distribution and abundance of animals, The University of Chicago Press, Chicago, Illinois

Batley M., Hogendoorn K. (2009) Diversity and conservation status of native Australian bees, Apidologie 40, 347-354.
Biesmeijer J.C., Roberts S.P., Reemer M., Ohlemueller R., Edwards M., Peeters T., Schaffers A., Potts S.G., Kleukers R., Thomas C.D., Settele J., Kunin W.E. (2006) Parallel declines in pollinators and insect-pollinated plants in Britain and the Netherlands, Science 313, 351-354.

Brook B.W., Sodhi N.S., Bradshaw C.J.A. (2008) Synergies among extinction drivers under global change, Trends Ecol. Evol. 23, 453-460.

Buchmann S.L., Nabhan G.P. (1996) The forgotten pollinators, Island Press, Shearwater books, Washington DC.

Byrne A., Fitzpatrick Ú. (2009) Bee conservation policy at the global, regional and national levels, Apidologie 40, 194-210.

Co-op (2009) The Co-operative Society of the UK. [online] http://www.co-operative.coop/ ethicsinaction/takeaction/planbee (accessed on 5 March 2009).

Costanza R., d'Arge R., de Groot R., Farber S., Grasso M., Hannon B., Limburg K., Naeem S., O’Neill R.V., Paruelo J., Raskin R.G., Sutton P., van den Belt M. (1997) The value of the World's ecosystem services and natural capital, Nature 387, 253259.

Cox-Foster D.L., Conlan S., Holmes E.C., Palacios G., Evans J.D., Moran N.A., Quan P.-L., Briese T., Hornig M., Geiser D.M., Martinson V., vanEngelsdorp D., Kalkstein A.L., Drysdale A., Hui J., Zhai J., Cui L., Hutchison S.K., Simons J.F., Egholm M., Pettis J.S., Lipkin W.I. (2007) A Metagenomic Survey of Microbes in Honey Bee Colony Collapse Disorder, Science 318, 283-287.

De La Rúa P., Jaffé R., Dall'olio R., Munoz I., Serrano J. (2009) Biodiversity, conservation and current threats to European honeybees, Apidologie 40, 263-284.

Dietemann V., Pirk C.W.W., Crewe R. (2009) Is there a need for conservation of honeybees in Africa? Apidologie 40, 285-295.

Eardley C.D., Gikungu M., Schwarz M.P. (2009) Bee conservation in Sub-Saharan Africa and Madagascar: diversity, status and threats, Apidologie 40, 355-366.

Elias M., Hill R.I., Willmott K.R., Dasmahapatra K.K., Brower A.V.Z., Mallet J., Jiggins C.D. (2007) Limited performance of DNA barcoding in a diverse community of tropical butterflies, Proc. R. Soc. London B 274, 2881-2889.

Ellis J.S., Knight M.E., Darvill B., Goulson D. (2006) Extremely low effective population sizes, genetic structuring and reduced genetic diversity in a threatened bumblebee species, Bombus sylvarum (Hymenoptera: Apidae), Mol. Ecol. 15, 43754386.

Fitzpatrick Ú., Murray T.E., Paxton R.J., Breen J., Cotton D., Santorum V., Brown M.J.F. (2007) Rarity and decline in bumblebees - a test of causes 
and correlates in the Irish fauna, Biol. Conserv. 136, 185-194.

Foley J.A., DeFries R., Asner G.P., Barford C., Bonan G., Carpenter S.R., Chapin F.S., Coe M.T., Daily G.C., Gibbs H.K., Helkowski J.H., Holloway T., Howard E.A., Kucharik C.J., Monfreda C., Patz J.A., Prentice I.C., Ramankutty N., Snyder P.K. (2005) Global consequences of land use, Science 309, 570-574.

Freitas B.M., Imperatriz-Fonseca V.L., Medina L.M., Kleinter A.M.P., Galetto L., Nates-Parra G., Quezada-Euán J.J.G. (2009) Diversity, threats and conservation of native bees in the Neotropics, Apidologie 40, 332-346.

Klein A.-M., Vaissière B., Cane J.H., Steffan-Dewenter I., Cunningham S.A., Kremer C., Tscharntcke T. (2007) Importance of pollinators in changing landscapes for world crops, Proc. R. Soc. London B 274, 303-313.

Malone L.A., Todd J.H., Burgess E.P.J., Philip B.A. (2005) Will GM crops expressing insecticidal proteins harm honey bees? Aspects Appl. Biol. 74, 115-118.

Memmott J., Waser N.M., Price M.V. (2004) Tolerance of pollination networks to species extinctions, Proc. R. Soc. London B Biol. Sci. 271, 26052611.

Murray T.E., Kuhlmann M., Potts S.G. (2009) Conservation ecology of bees: populations, species and communities, Apidologie 40, 211236.

Oldroyd B.P., Nanork P. (2009) Conservation of Asian honey bees, Apidologie 40, 296-312.

O'Callaghan M., Glare T.R., Burgess E.P.J., Malone L.A. (2005) Effects of plants genetically modified for insect resistance on nontarget organisms, Annu. Rev. Entomol. 50, 271-292.

Parmesan C., Ryrholm N., Stefanescu C., Hill J.K., Thomas C.D., Descimon H., Huntley B., Kaila L., Kullberg J., Tammaru T., Tennent W.J.,
Thomas J.A., Warrant M. (1999) Poleward shifts in geographical ranges of butterfly species associated with regional warming, Nature 399, 579-583.

Patiny S., Michez D., Rasmont P. (2009) A survey and review of the status of wild bees in the WestPalaearctic region, Apidologie 40, 313-331.

Roubik D.W. (2001) Ups and downs in pollinator populations: When is there a decline? Conserv. Ecol. 5, 2. [online] http://www.consecol.org/vol5/iss1/ art2/ (accessed on 3 March 2009).

Stout J.C., Morales C.L. (2009) Ecological impacts of invasive alien species on bees, Apidologie 40, 388-409.

Tilman D., Fargione J., Wolff B., D'Antonio C., Dobson A., Howarth R., Schindler D., Schlesinger W.H., Simberloff D., Swackhamer D. (2001) Forecasting agriculturally driven global environmental change, Science 292, 281-284.

United Nations (2004) World Population to 2300, New York. [online] http://www.un.org/esa/population/ publications/longrange2/WorldPop2300final.pdf (accessed on 3 March 2009).

Williams N.M., Minckley R.L., Silveira F.A. (2001) Variation in native bee faunas and its implications for detecting community changes, Conserv. Ecol. 5, 7. [online] http://www.consecol.org/vol5/iss1/ art7/ (accessed on 3 March 2009).

Williams P.H. (1982) The distribution and decline of British bumble bees (Bombus Latr.), J. Apic. Res. 21, 236-245.

Williams P.H., Osborne J.L. (2009) Bumblebee vulnerability and conservation world-wide, Apidologie 40, 367-387.

Williams P.H., Araújo M.B., Rasmont P. (2007) Can vulnerability among British bumblebee (Bombus) species be explained by niche position and breadth? Biol. Conserv. 138, 493-505.

Zayed A. (2009) Bee genetics and conservation, Apidologie 40, 237-262. 